\title{
An ethical analysis of the implementation of poverty reduction policies in South Africa and Chile and their implications for the Church
}

\author{
Author: \\ Louise Kretzschmar ${ }^{1}$ \\ Affiliation: \\ ${ }^{1}$ Department of Philosophy, \\ Practical and Systematic \\ Theology, University of \\ South Africa, South Africa \\ Correspondence to: \\ Louise Kretzschmar \\ Email: \\ kretzl@unisa.ac.za \\ Postal address: \\ PO Box 392, UNISA, \\ Pretoria 0003, South Africa \\ Dates: \\ Received: 11 Sept. 2013 \\ Accepted: 22 Mar. 2014 \\ Published: 17 Sept. 2014 \\ How to cite this article: \\ Kretzschmar, L., 2014, \\ 'An ethical analysis of the \\ implementation of poverty \\ reduction policies in South \\ Africa and Chile and their \\ implications for the Church', \\ HTS Teologiese Studies/ \\ Theological Studies 70(1), \\ Art. \#2069, 11 pages. http:// \\ dx.doi.org/10.4102/hts. \\ v70i1.2069
}

\section{Copyright:}

(C) 2014. The Authors.

Licensee: AOSIS OpenJournals. This work

is licensed under the Creative Commons

Attribution License.
Read online:
The focus of this contribution is the issue of poverty reduction within the South African and Chilean contexts. It is rooted in the academic field of Christian Ethics and also draws on several texts from the human and economic sciences. Policies adopted and practical steps taken to overcome poverty by the respective governments between 1990 and 2012 are evaluated and the theological and practical implications of poverty for the church are briefly highlighted. Despite differences between these two countries, South Africans can learn much from the Chilean policy and its implementation.

\section{Introduction}

In 2012 I attended the Baptist World Alliance conference in Santiago, Chile where an earlier form of this article was presented to the Ethics Commission. ${ }^{1}$ In my research and following conversations with Chileans at the conference, I was struck by several similarities (and dissimilarities) between Chile and South Africa. I do not pretend to be an expert in Chilean matters, but I was impressed by what the Chilean people had achieved in terms of poverty reduction over the past two decades. The reason for embarking on this brief comparative study is to ascertain what South Africans, including church communities, can learn from the ongoing Chilean theoretical analysis and dedicated application. Hence, the aim of this article is to evaluate the policies developed by the Chilean and South African governments to reduce poverty and the success of the governments' implementations from the perspective of Christian ethics. ${ }^{2}$ The bulk of this article will deal with the economic policies of South Africa and Chile since approximately 1990. This article will also draw on empirical and other studies conducted on poverty from the human and economic sciences. It will also seek to draw out the ethical implications of the development, use and distribution of resources. This interplay between practical experience and theoretical concepts is central to an interdisciplinary Christian ethical approach.

\section{Christian ethics}

Ethical analyses of poverty reduction within different academic disciplines and society as a whole need to investigate how economic systems function, who benefits from them and how they can be altered to increase both production (without destroying the environment) and the equitable distribution of the results of all forms of economic endeavour. Christians ought to draw on their particular understandings of reality and morality and be involved in this dialogue by interpreting the available data, identifying additional data, and contributing at an intellectual and practical level. Christian ethics can be defined as both the rational investigation of what is right, good, true, wise and loving and as an exercise in moral imagination based on a moral vision of God's purposes for the world. But Christian ethical reflection must be accompanied by the formation of Christian virtues, character and community and the expression of Christian norms and values in moral courage and action. While Christians hope for a better world that God will bring about, the way we live in the here and now is important.

This is not the place to venture into a detailed discussion of the Bible and the economy, hence only a few examples of key ethical teaching and principles are provided below. Old Testament prophetic books such as Isaiah give extensive expression to God's expectations that social justice (Is $1: 16-17 ; 56: 1-2$ ) and practical concern for the plight of the poor (Is $3: 14-15 ; 10: 1-2$ ) ought to be a feature of national life. In Amos (2:6-7; 4:1-3; 8:4-6) also, God's judgement on those who 'grind the faces of the poor' is announced. The justice, righteousness and mercy of the reign of the

1.The Baptist World Alliance (2014) is a fellowship of 228 conventions and unions in 121 countries and territories comprising 42 million members in 177000 churches. Its priorities are nurturing the passion for mission and evangelism, promoting worship, fellowship and unity, responding to people in need, defending human rights and justice and advancing relevant theological reflection. 
promised Messiah (Is 9:1-7; 11:1-9; 42:1-4) is contrasted with false religion (Is 58:1-14) and the immoral and oppressive actions of human rulers (Is 28:1-29; 59:1-21).

Jesus' own teachings and example about poverty and wealth are instructive at both a personal and structural level. On the one hand Jesus expresses concern for the poor and recognises the importance of food, health and physical well-being. He begins his public ministry by declaring: 'The Spirit of the Lord is upon me, because he has anointed me to bring good news to the poor' (Lk 4:18), he further feeds the poor (Mt 14:13-21; 15:32-39) and heals the sick (e.g. Mt 14:34-36; 15:29-31). On the other hand Jesus stresses the the dangers of avarice, which is the excessive desire for money and possessions (Lk 11:37-40; 16:14). He teaches against the perils and foolishness of greed, selfishness and hoarding (Lk 12:13-21), being dishonest, a lover of money and indifference towards the poor (Lk 16:1-31). What one treasures or values (Mt 6:19-21; Tobit 4:8-9), will determine whether one serves God or mammon (Mt 6:24). According to Stassen and Gushee (2003):

... [I]n a context characterised by extraordinary economic exploitation in Jesus' own day and long economic depression in Matthew's time, Jesus was teaching about the kind of compassionate and merciful justice that delivers the poor from poverty and restores them into community ... [it is] a summons to serve God's compassionate reign through acts of justiceadvancing compassion towards the economically vulnerable and oppressed. (p. 413)

In short, the convictions and actions of Christians about the economy cannot be separated from their spirituality (faith) or their ethical norms, values, virtues and actions.

A theological ethic has been part of Christian thought and action for centuries. Theologians and many others within the Christian tradition, admittedly influenced by their various contexts, have addressed economic justice both in their theology and in practical ways, a few of which can be mentioned here.

In the 3rd century, Clement of Alexandria (in Wogaman \& Strong 1996:33-37) asked: 'Who is the rich man that shall be saved?' St Basil the Great (329-379), together with members of his family, dedicated himself to God and made use of his family's fortune to care for the poor, foster learning, and establish a hospital. He said:

Are you not a robber, who consider your own that which has been given you solely to distribute to others? This bread which you have set aside is the bread of the hungry; this garment you have locked away is the clothing of the naked; those shoes which you let rot are the shoes of him who is barefoot; those riches you have hoarded are the riches of the poor. (in Ellsberg 1997:258-259)

St Francis of Assisi (1182-1226) is well known for his dedication to the poor. In a context of rapid social change and great poverty among the common people, his Franciscan order both exposed social inequalities and cared for the poor (Tastard 1989:11-37). Especially during the medieval period, monastic orders such as the Benedictines and others played a significant role in the provision of food, welfare and medical care to the poor. They further contributed to social well-being, knowledge and technical expertise through their agricultural and architectural innovations, their expertise in construction and their preservation of scrolls, books and learning. Consequently, Henry VIII's dissolution of the monasteries in England in the 16th century resulted in the increase of poverty during Tudor times in England.

During the evangelical revival in England in the 18th century, the ministry of the brothers John and Charles Wesley, and in the early 19th century many other religious leaders (e.g. William Wilberforce, the Earl of Shaftsbury and Elizabeth Fry $)^{3}$ made a significant impact on the lives of agricultural labourers, prisoners, slaves, miners, orphans, the sick and the dispossessed. In the second half of the 19th century, the writings of F.D. Maurice and, later, Walter Rauschenbusch and the Social Gospel movement (Wogaman 1993:194-208), addressed the economic challenges of their time. Also, Catholic Papal Encyclicals, ${ }^{4}$ Protestant and ecumenical social ethics (Fourie 2012:49-50; Wogaman 1993:209-216) addressed social relations, economic justice, poverty, the working classes, industrialisation and social ethics. During the 20th century, the rise of liberation theology placed economic matters high on the social agenda (Gorringe 2001:125-137; Gutiérrez 1974, 1984). The witness of prominent leaders such as Dom Helder Camara and Archbishop Oscar Romero in Latin America, and Desmond Tutu in South Africa, along with the dedicated ministries of many ordinary believers, have borne witness to the social and economic teaching of the church.

As Christian ethics is rooted in and motivated by a Christian spirituality, any discussion of a concrete and complex moral problem such as poverty needs to investigate what the implications of an authentic spirituality are. Thus, for both individual believers and communities of believers, a genuine faith effects a progressive change in world view, attitudes, character and conduct, as can be seen in the lives of countless Christians throughout the ages (Ellsberg 1997; Quinn 2002). ${ }^{5}$ It issues in the willingness to work actively for social, economic and environmental justice at both personal and structural levels in a courageous and compassionate manner. A deepening spiritual consciousness is needed both to nurture the wellsprings of action and to prevent the growth of selfishness, arrogance and self-righteousness. Hence, for Christians spirituality and ethics cannot be separated; a holy life is also a good life. ${ }^{6}$

Some readers may remember the impact made by Ron Sider's classic text, Rich Christians in an age of hunger (1977). However,

3.For a discussion of the role of Baptists in education and society, see Briggs (1994:340-405).

4.For example, John XXIII (1961) Mater et magistra, Pius XI (1981). Quadragesimo anno and John Paul II (1990) Solicitudo rei socialis.

5.Despite the many spelling errors in Quinn's book, it outlines the impact of Christians on Africa.

6.See Volf (2011:3-54) on malfunctions of religion such as idleness and coerciveness. 
as Stassen and Gushee note (2003:410, 426), rich nations and many Christians within them - remain captivated by the materialism of the age. Similarly, the love of mammon is not absent from poorer nations in Africa where ruling elites have become corrupt and self-serving (Mills 2010; Wrong 2009). Ramphele (2012:6) speaks of the 'capture' of the South African state by a 'patronage-driven system'.

Thus, the following are some of the key moral issues related to poverty: a clear understanding of the nature and causes of poverty; clarity about who benefits from the economic systems, structures and policies in a particular country; how poverty can be substantially reduced; and what role the church can play in all of this. The discussion now turns to a consideration of poverty and its reduction in Chile and South Africa.

\section{What is poverty?}

In purely economic terms, poverty can be defined as 'the inability of individuals, households or communities to command sufficient resources to satisfy a socially acceptable minimum standard of living' (Childhood Poverty in South Africa 2002:1 of 4). However, as noted in the following sections of this article, poverty can also be defined more relationally and holistically, as including the exclusion or exploitation of particular groups, historical and systemic discrimination, and the lack of education or opportunity to access the economy. There is a close relationship between hunger and poverty. Globally, approximately $70 \%$ of malnourished children live in Asia, 26\% in Africa and 4\% in Latin America and the Caribbean. The main causes of hunger are poverty, harmful economic systems, conflict, and climate change (World Hunger Education service 2013). Poverty also retards family well-being and prevents people from contributing to their society. Unemployment, as noted below, is a major factor in the increase of poverty.

In personal, practical terms, poverty is brutal human experience of ill health, unemployment, struggle and a sense of powerlessness to affect change. Let me share the story of a woman I knew. Sarah (not her real name) was born in a poverty-stricken area of the Eastern Cape in the 1940s. She married and had a family. Then her husband, who had been employed, died. The only relatively well-paid work she could find was domestic work over the Christmas and Easter periods. Initially, she did agricultural, seasonal work which involved back-breaking toil. As she grew older, it was no longer possible for her to perform this work. In the meantime, her children had reached maturity, but were all unemployed. Her sons were not only unable to provide for the family, but were also involved with a gang of disruptive young men. Her two daughters became pregnant while at secondary school, adding more responsibility to the already oppressive economic burden carried by Sarah. Eventually, Sarah became ill but was afraid to obtain medical assistance. By the time cervical cancer was diagnosed, she was months away from death. Today, her children are motherless and unemployed, subsisting on occasional work and making use of childcare grants to support themselves and Sarah's grandchildren. This tragic story is repeated in different forms throughout South Africa and it ought to motivate government and the church to engage in effective care and action.

\section{Poverty reduction in Chile}

The current inhabitants of Chile, like South Africans, can look back on a long pre-colonial heritage, the imperialism of foreign nations (in the 16th century Chile was invaded by Spain) and the immigration of settlers. The indigenous people of both countries were defeated militarily, exploited and marginalised, but in South Africa they form the majority of its inhabitants. In 1818, Chile declared its independence from Spain (along with many other Spanish South American colonies during this period). Since the start of the 20th century, several governments have had an impact on Chile. From 1973, following a coup d'état, the Pinochet government was in power until the plebiscite of 1988 . This was followed by a transitional period and the new government was elected in 1990. Thereafter, several left-of-centre socialist governments under various presidents have ruled the country.

\section{Chile: Facts and figures related to poverty}

Between the 1930s and 1973, the State sought to fight poverty by improving access to social rights, but poverty and social division increased significantly (Palma \& Urzúa 2005:12 of 36). In 1973, the army general, Augusto Pinochet, seized power from Salvador Allende's elected socialist government and a period of draconian political repression ensued, reminiscent of the attempts of the Nationalist government in South Africa to retain power between 1948 and 1990. Some attempt was made to address poverty, but neo-liberal policies (influenced by the thinking of Milton Friedman and the 'Chicago Boys') tended to cut social spending during times of low growth, leading to greater poverty.

Following the return to democracy in 1990, a twofold focus, firstly on the improvement of social services (e.g. health, housing and education) and secondly on specific programmes to assist the poor, was adopted (Palma \& Urzúa 2005:14 of 36). Prior to 1990,40\% of the population were classified as poor, but by the year 2000, 'poverty was

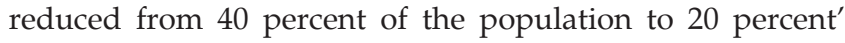
(Foxley 2004:1 of 20) Other figures (Palma \& Urzúa 2005:15 of 36) state that the number of poor people fell from $25.7 \%$ in 1990 to $14.9 \%$ in 2000 , and of the indigent (or ultra-poor) from $12.9 \%$ in 1990 to $5.7 \%$ in 1996 .

\section{Policies, strategies and their implementation}

At a conference held in Shanghai in May 2004, Foxley (2004: 1 of 20) reported on the successes of and failures in poverty eradication in Chile. He pointed out the economic factors which had enabled Chile to reduce poverty significantly:

- opening the economy to world trade

- conservative fiscal policies that ensured both a budget surplus and the reduction of public debt 
- expanding the domestic capital market

- the reform of labour and tax policies, including a tax increase that allowed the government to expand social expenditures by more than $200 \%$ through the 1990 s.

The implementation of these strategies made it possible for the economy of Chile to grow at $6 \%$ for a 10 -year period:

The combination of high growth and active redistributive policies reduced by nearly one-half the extreme income disparity between the top 20 percent and the lowest 20 percent of the population ... about 60 percent of Chile's poverty eradication in the 1990s can be attributed to economic growth and 40 percent to social policies. (Foxley 2004:1 of 20, [my emphasis])

In Chile, it was found that it was easier to assist those who were just below the poverty line than those in extreme poverty. From 1994, the government first sought to solve this problem through the National Program of Poverty Eradication, and then from 2002 onwards through a revised strategy, the Chile Solidario programme. Even after the recession of the late 1990s, the rate of poverty continued to decline because government could spend the financial surplus gathered during the earlier 'fat' years on protecting and empowering those who were poor and unskilled. This was in marked contrast to the decrease in social expenditure of the Pinochet government in the late 1980s which reduced social services, salaries and old-age pensions and resulted in extreme hardship for the poor.

During the left-of-centre governments of Presidents Aylwin, Frei and Lagos, pro-growth strategies and tax reform meant that increased jobs and wages led to further poverty reduction. The population largely accepted tax increases in the hope that poverty reduction would bring about greater social stability, economic growth and foreign investment. The lessons learnt from Chile were that economic growth was only one of several important factors. To change poverty you need:

- some economic growth

- government social spending to generate jobs

- food education - otherwise well-paid jobs cannot be accessed

- health - otherwise people cannot work well or regularly. 'By 1990 93\% of the population had access to health care services' (Olavarria-Gambi 2003:116 of 123), even though the health service was not always very efficient, except in emergency cases.

What were some of the problems experienced in this fight against poverty? It has been argued that these included the self-protectiveness of the various labour unions in Chile, which resisted change and hampered the attempts of the government to bring the 'outsiders' (unemployed or partly employed) into the economy (Foxley 2004:16-17 of 20). For instance, it became important to link public expenditure to the cooperation and effectiveness of the health workers. Foxley (2004) comments:

Rigid, highly centralized, bureaucratic institutional arrangements in public hospitals, combined with active resistance from doctors and public health workers, resulted in great inefficiency. Although government expenditures in public health increased by 250 percent, the output of healthcare services grew only by 22 percent. (p. 2 of 20$)$

Hence, social programmes needed to overcome rigid and ineffective government bureaucracies by employing professional, well-trained and motivated personnel who could provide the required services in an efficient way, in an increasingly decentralised public sector where accountability was central. ${ }^{7}$

Another key strategy of poverty alleviation was the improvements in education. But there, too, the government faced resistance from teachers and unions about wage negotiations, security of employment and performance. Foxley (2004) is of the opinion that:

A lesson from Chile's experience is that in some cases it probably pays to confront the vested interests of teachers and health workers up front. The number of days lost in strikes, even the political costs to the government, will be rapidly compensated by immense welfare gains, as more flexible, decentralized, incentives and user-oriented social services are provided. (p. 11 of 20)

A further important factor was the focus on the family. Families with problems of abuse, malfunction, extreme poverty and despair find it difficult to access social assistance due to lack of cohesion, cooperative effort and motivation. As noted earlier, the Chile Solidario programme or policy was initiated in 2002. It was family-centred and used several ways to combat poverty. It sought to respond to the need for social capital (e.g. skills development), social networks (the impact of combining resources) and short-term crisis intervention. The system included psychosocial support, protection bonds, guaranteed monetary subsidies, preferential access to programmes that developed skills, work and social programmes (Palma \& Urzúa 2005:6 of 36).

An element within the overall Chile Solidario programme was the Programa Puente [Bridge Programme] approach that was implemented between 2002 and 2005. It used 53 'life quality standards' by which the progress of extremely poor families could be measured. These standards included obtaining identification documents, cleaning up their houses, and accessing skills training programmes. This Programa Puente approach emphasised 'a personal relationship between a professional and each family' for a 24-month period. Within this programme, the family was regarded as an essential part of social protection and advancement policies. Between May 2002 and June 2004, 31.9\% of the participating families 'achieved their 53 life standards' (Silva 2004:3 of 5).

Finally, the Chile Solidario programme required cooperation between different government departments at national, regional and municipal levels and was centralised in the Planning Ministry which reported directly to the president 7.See Habib (2013a, 2013b:60-62) for a discussion of the difficulties of professionalising the public service in South Africa. 
(Palma \& Urzúa 2005:23 of 36). This co-ordinated effort brought concrete improvements in the lives of poor families. It was also suggested that the Chile Solidario policy be further extended beyond particular families to include links with other families and greater social participation in the community (Palma \& Urzúa 2005:32-33 of 36).

According to Mark Schmidt (2010:1 of 4), despite its many successes, Chile still remains an extremely unequal country, ' $[t]$ he wealthiest $10 \%$ of Chileans earn $42 \%$ of the country's output, making Chile as unequal as Nicaragua, and only slightly less stratified than Brazil or Bolivia.' Remarkable success was achieved in reducing poverty from 38.2\% in 1990 to $15.6 \%$ in 2010, but because the incomes of the rich have also risen, a significant economic gap persists. But the achievements of helping families to function better, improving the health and education systems, developing skills, ensuring economic growth and employment now provide a foundation to further reduce the economic gap.

\section{Poverty reduction in South Africa}

South Africa, like Chile, experienced conquest, imperialism, colonial and settler rule - all of which dispossessed and displaced the indigenous San, Khoi and African inhabitants. The Cape was settled first by the Dutch in 1652 and, later, by the British with the second occupation of 1806 . The earlier years of the 20th century were marked by the end of the second Anglo Boer War (1902) and, in 1910, the establishment of a white South African government in the form of the Union of South Africa. The Land Acts of 1913 and 1936 deprived the majority of black people of access to land. Following the victory of the Nationalist Party in 1948, successive Acts of parliament further deprived black people of access to political and economic power. In South Africa, both colonialism and the policy of apartheid (1948-1994) resulted in skewed land ownership, ${ }^{8}$ the restriction of the movement of black people, discrimination in terms of employment and education, economic exploitation, disenfranchisement and state violence. In 1994, the first non-racial democratic elections were held. Since then, the African National Congress (ANC) has been the ruling party.

\section{South Africa: Facts and figures related to poverty}

The extent of poverty in South Africa has always been worse than in Chile. In 1995, it was estimated that 18 million people in South Africa could be classified as poor and a further 10 million as ultra-poor. ${ }^{9}$ All racial groups are affected by poverty, but black Africans are worst affected. According to Aliber (2003:475), '72\% below the poverty line reside in rural areas, and $71 \%$ of all rural people are poor.' In addition to the rural poor, female-headed households, people with disabilities, the elderly, retrenched farm workers, cross-border migrants, 'street homeless', AIDS orphans and households with AIDS sufferers are the most affected by poverty (Aliber 2003:482).

8.See Hall (2009) for a detailed discussion of policy options regarding land redistribution.

9.Terreblanche (2004:214-225) discusses the incidence of poverty prior to 1994.
In 2002, it was estimated that 'between 45 and 55\% of all South Africans live in poverty, depending on the poverty measure used' and that 11 million children under 18 years of age are living in poverty (Childhood poverty in South Africa 2002:1-2 of 4).

Since 1994, several key factors (Terreblanche 2004:225-228) have inhibited poverty reduction: the number of unemployed people has increased; current economic policies are not benefitting the poor (except in terms of welfare grants); the lack of organisation at the community level that can effect change; the lack of education; and the negative effects of crime, violence and infectious diseases.

A study done at the University of Stellenbosch (Armstrong, Lekezwa \& Siebrits 2008:3) noted the following key 'poverty markers': 'geographical location, population group, gender, household structure, the age of the head of the household, and employment status' together with 'deficient access to infrastructure services, high transport cost burdens, limited education attainments, and exposure to hunger.' This study noted that the increased government social grants as of 1999 had notably decreased high levels of poverty. But, women, children and the elderly remained very negatively affected. In South Africa, patriarchy is still a significant factor, resulting in women experiencing not only the brutal realities of poverty, but finding it difficult to alter their circumstances. Children, women, the elderly and disabled are more negatively affected by poverty than men. Furthermore, the 'skewed distribution of wealth' (the Gini-coefficient) has increased since 2006 and the high number of HIV-infected persons - about 5.6 million in 2011 - (Avert 2012:1 of 98) has been an obstacle to decreasing poverty levels (Kretzschmar \& Snyman 2008:198-220).

Women's lives are deeply affected by unemployment, family dysfunction, HIV/AIDS, and violence. Even when they do find employment, many women are part-time workers in semi- or unskilled employment which is not well paid. According to Moletsane et al. (2010:1, 36-7 of 171), the gender dimension of poverty reduction is often neglected in policy development. They suggest the importance of the 'Voice' of women (as opposed to their marginalisation), 'Dialogue' (so that women are part of strategic decisionmaking) and 'Targeting' (to ensure that the implementation of policies has an effect on women's lives). Furthermore, greater policy coherence, the integration of gender in the understanding of poverty, safe transport, childcare options and the greatly increased involvement of men in childcare are key factors to enable women and children to emerge from the trap of poverty.

What has been achieved so far? Aliber (2003) reported:

Since 1994, the various infrastructure programmes have resulted in improved access to safe water for four million people, improved sanitation services for over three million people, 600 new clinics, over one million residential units, and 1.5 million more households connected to the electrical grid. (p. 476) 
The number of black people in the middle class bracket has grown significantly, but millions of people do not have sufficient food, clothing, employment or proper housing. It was reported in 2006 that 21.9 million people - nearly half of the population - live below the poverty line (Diakonia 2006:17). Since then, a further 1.7 million houses have been built, infant mortality and illiteracy rates have been reduced, and access to free education increased. Yet service delivery protests have also increased exponentially.

According to Terreblanche (2004:214), and Vorster (2007:64), the poor are getting poorer. ${ }^{10}$ Using data compiled by the United Nations Development Programme and Statistics South Africa, Terreblanche shows that the poverty index improved between 1995 and 2000. But, the number of South Africans below the poverty line increased from 20.2 million in 1995 to 21.9 million in 2002. In 1995, 3.7 million lived on less than $\$ 1$ a day, and in 2002, this was true of 4.7 million people. Old age pensions have long been a feature of the social welfare system in South Africa. In recent years, school feeding schemes have been reintroduced and child grants, disability grants and other means of social assistance have been introduced. These forms of social assistance have proved to be effective in terms of poverty alleviation, but not in terms of poverty reduction.

According to Statistics South Africa (2011), as of the 4th quarter of 2011, unemployment grew from about 3.9 million to about 4.2 million persons in South Africa between 2008 and 2011. This amounts to a current official rate of approximately $25 \%$ unemployment. But this figure does not include the approximately two million people who have given up looking for work. In 2010, 51.3\% of young people between the ages of 15 to 20 years, and $29 \%$ of those between 25 and 34 were unemployed (Ramphele 2012:3). No country can be socially stable or economically prosperous with such high rates of unemployment exacerbating the experience of poverty.

\section{Policies, strategies and their implementation}

During the 20th century, South Africa has seen the introduction of many policies and strategies to reduce and eliminate poverty. In 1922, in the face of the 'poor white problem' following the Anglo Boer War and the Great Depression, the first Carnegie enquiry on poverty was initiated. In 1983, a second Carnegie conference was held to address poverty amongst black South Africans. Initially, the focus of attention was on economic growth as the means to address poverty. This approach assumed that there would be an effective 'trickle-down' effect whereby members of society at the bottom of the economic ladder would eventually benefit. In 1995, a series of investigations and reports were initiated by the South African government, with the assistance of the World Bank. By 1998, the following recommendations about how poverty could be reduced in South Africa were made (May 1998:6-11). These included:

- linking economic growth and human development

- the redistribution of assets and opportunities

10.See McGuigan (2009:261-283) for a discussion of the problem of increasing debt.
- market reforms

- spatial and infrastructural development

- institutional reforms.

Today, many commentators are agreed that a combination of factors such as infrastructural improvement, appropriate government intervention, land redistribution, labour law reforms, trade and the growth of the small and medium business sector are essential for economic growth. Government can also provide social spending in terms of welfare grants, food support for children and the provision of credit. Thus, according to May (1998:2), '... while growth is a necessary condition for the alleviation of poverty, it is not a sufficient condition' - as was seen in the earlier discussion of poverty reduction in Chile.

Government economic policies since 1994 have included the Reconstruction and Development Programme (RDP) in 1994, Growth, Employment and Redistribution (GEAR) in 1996, the Accelerated Shared Growth Initiative for South Africa (ASGISA) in 2006, the New Growth Plan (NGP) in 2010 and, most recently, the National Development Plan (Department of the Presidency) in 2013. ${ }^{11}$ According to Trevor Manuel's speech to Parliament delivered on 15 August 2012 and adopted by the ANC in December of the same year, the 484-page National Development Plan (Department of the Presidency 2013) rests on the following six pillars: 'to unite all South Africans around a common programme to fight poverty and inequality and to foster a spirit of unity'; an active citizenry; a growing and inclusive economy; to build capabilities; a capable and developmental state; and 'the responsibilities of leadership throughout society to work together to solve our problems'(Manuel 2012). But, in order for an effective strategy to be developed and implemented, as was the case in Chile, policy agreement and consistency on the part of government and of other stakeholders is a prerequisite to reduce poverty in an effective manner. ${ }^{12} \mathrm{On}$ 22 July 2013, ANC secretary general, Gwede Mantashe, reportedly said: 'It is time to start implementing the National Development Plan (Department of the Presidency 2013) and stop debating it', this is because both the Congress of South African Trade Unions and the South African Communist Party have 'voiced concerns about certain sections of the NDP' (Quintal 2013). Hence, substantial policy agreement between government and civil society does not yet exist.

In addition to policy coherence and consensus, the actual implementation of policy is required if specific strategies including land reform, housing, microfinance, and the improved infrastructures for the supply of water, sewage, electricity, transport, health provision and education are to be achieved. But, such implementation depends on the commitment and ability of government officials. And, as was the case earlier in Chile, this is precisely where the problem lies. The implementation of poverty reduction has been

11.The latter two are compared by Adam Habib (2013a) where he stresses the need for both social democracy and a mixed economy.

12. Habib (2013b:102-109) argues that the NDP calls for a social pact among stakeholders, but not all accept its neo-Keynesian economic approach. 
hampered by corruption, indifference to the plight of the poor and what is euphemistically termed 'lack of capacity'. For example, the Department of Land Affairs has achieved very little in the way of land redistribution despite clear policy guidelines, and has been dogged by serious allegations of corruption and inefficiency. Given that the main responsibility for the improvement of infrastructure and services has been devolved to the provinces and local municipalities, it is vital that they function effectively. However, according to the Provincial (regional) audit outcomes of 17 January 2012, a few provinces have fared well, but many have failed dismally. According to the media release of the office of the Auditor-General, 'Of the 536 audited entities, only 117 (22\%) have received clean audit opinions' (Auditor-General South Africa 2013).

These included the Northern Cape, Southern Cape and North West. Over the 2010-2011 financial year 52\% of all reports were qualified with several still outstanding (Provincial audit 2012). Local municipalities fared even worse. Significantly, government itself reported these key problems: inefficient and ineffective administrations; inappropriate political interference; poor political and administrative oversight; weak compliance; the inability to respond to the complexity of demands and expectations; and huge variables in spatial location, skills base and socio-economic legacies (State of Local Government in South Africa 2009:33).

In February 2012, President Jacob Zuma announced in his State of the Nation speech that Government would engage in a massive project of infrastructure development. Helen Zille, the leader of the opposition Democratic Alliance (DA) applauded the government plan to provide additional 'water, energy, technology, transport and roads and sewage systems', but she pointed out that the State is falling very short in terms of the implementation of its tasks. The problems highlighted by Zille (2012) included:

- Political appointments at municipal and other levels of government meant that these appointees did not have the competence to perform their tasks.

- The inefficiency of the national rail network (Transnet) and the port authorities.

- High levels of corruption.

- Insufficient skills to implement infrastructural development and ongoing problems in the provision of effective primary, secondary and tertiary education.

- Inefficient and rigid bureaucracies which prevent the granting of work permits for foreigners who are willing to work, invest or open businesses in the country.

What of the health and education sectors? The current Minister of Health, Aaron Motsoaledi, is faced with the huge task of turning around the national hospitals that have severely deteriorated since 1994. South Africa has a long way to go in making effective, affordable health care accessible to all. As far as education is concerned, according to Armstrong et al. (2008), the correlation between poverty, unemployment or poor wages and the lack of education is very significant:

Some $88 \%$ of the individuals aged 15 and above who lived below the 'lower-bound' poverty line had no schooling (14.9\%), an incomplete primary-school education $(21.5 \%)$ or an incomplete secondary-school education (52.0\%). Only $10.5 \%$ of the poor held matric, while a mere $0.7 \%$ had obtained a post-graduate certificate, diploma or degree. (p. 19)

Since 1994, the money spent on schooling has increased significantly. However, 'throwing money' at a problem does not automatically solve it. Key problems include badly conceived educational policy, the inept implementation of decisions and the lack of managerial capacity at all levels. Outcomes Based Education, for example, was poorly understood and seriously mismanaged. Also vital is the provision of competent dedicated and effective teaching, especially at the levels of primary and secondary education. Why is it that powerful individuals or unions can prevent teachers who are lazy, corrupt or immoral from being dismissed? Other problems include the failure to supply textbooks, the lack of exercise of proper discipline, the need to supply well qualified and motivated teachers to replace those who will be retiring and the appalling drop in educational standards. On 09 January 2012, Prof. Jonathan Jansen (2012), the controversial, but widely-respected principal of the University of the Free State, said of government schooling:

I do not trust a system that makes it possible for a child to pass Grade 12 with $30 \%$ in some subjects and $40 \%$ in other subjects. I would be filled with fear when I discover that you can get $32 \%$ in mathematics and $27 \%$ in physical science and still get an official document that says you can continue to study towards a Bachelors degree at university. (p. 1 of 2)

Some students who enter the universities with a supposed 'university entrance pass' cannot cope with their studies due to deficient language and numeracy skills. Yet universities are financially penalised by the government if their 'throughput' rates are not high enough. Jansen (2012) continued:

Talk to any employer in business and industry and they will tell you the same story: today's graduates are weak, even incompetent, in the basic skills of reasoning, writing, and computing; they cannot work in teams; they are inarticulate in public; they cannot solve complex problems; they lack the rigour of hard work; there is, in other words, a huge gap between what the school or university diploma says, and what graduates can actually do in the real world. (p. 1 of 2)

Again, here South Africans can learn something from the Chileans. Without performance evaluations being applicable to all civil servants, the dismissal of officials guilty of corruption and 'lack of capacity' and a huge shake-up in terms of all levels of government, further improvements in the provision of basic services, let alone the significant reduction of poverty are simply not possible. It is striking that even though specific recommendations about poverty reduction policies and their implementation were available to the new government, the lives of the vast majority of especially black South Africans have not improved significantly over the 
past 19 years. Habib (2013b:60-71) argues that the blurred lines between different spheres of government, corruption, the effects of affirmative action, cadre and factional employment and lack of resources prevent effective service delivery. Habib (2013b:201-246) goes on to say that at a structural level, the key areas that require attention include reconstructing political accountability towards citizens, reconciling conflicting rights (e.g. economic growth and inclusive development, and affirmative action and service delivery), effective leadership, socio-economic justice and developing an inclusive understanding of citizenship.

\section{The role of the church}

The Catholic Church has historically been populous and powerful in Chile, with the Protestant churches being much smaller in number and influence. It is true that some within the Catholic Church, who supported the Pinochet government, were critical of liberation theology and resisted calls for the Church to be more involved in political resistance. But it is equally true that, along with other church leaders such as the Lutheran Bishop Helmut Frenz, Catholic archbishops such as Raul Silva Henriquez and Juan Fresno Larrain supported those who resisted political oppression. Through the work of groups like Peace Committee and the Vicaria de la Solidaridad, human rights abuses and the 'disappearance' of thousands of dissidents were exposed and the Catholic Church was a vital broker between Pinochet's government and those who resisted his rule during the transition to democracy (Frenz 2008:251-260; Meacham 1994:279-294). This Christian resistance drew on Papal encyclicals dealing with socioeconomic matters, the long-standing Catholic stress on the 'common good' and the need for the Church to be a 'voice for the voiceless'. Despite theological differences, the Catholic Church has maintained a practical concern for the poor, supported policy decisions to alleviate their plight and insisted on the need to reduce economic disparities. Hence the Catholic Church and other churches to a lesser extent have provided religious support for social change and the policies of poverty reduction in Chile.

In South Africa, in terms of the 2001 South African census, $79.8 \%$ of the population identified themselves as Christians. Churches include the Reformed churches, Anglicans, Methodists, Catholics, Pentecostals, Charismatics and many indigenous African churches. Even when one assumes that the number of committed Christians are fewer than the census figures, this still means that the churches cumulatively can wield influence over millions of the country's people. Above, a detailed analysis was provided to avoid a superficial discussion of the complexities of poverty reduction. In the following section some key theoretical and practical areas that require attention from different sectors of the church are identified.

\section{Credibility}

Although some Catholics initially supported Pinochet's coup d'état, many within the Church soon began to oppose the human rights abuses and policies of this period. Especially Cardinal Silva and Bishops Camus and Tomas Gonzalez made their resistance to the regime public. Silva was maligned and criticised by the government and in 1975, over 300 Catholic priests were deported (Davis 2007). But the churches continued to support the cause of democracy, assist human rights groups, provide legal and other assistance to those families whose members had 'disappeared' and it advocated for change locally and internationally.

Today, however, the power of the Catholic Church in Chile has declined and its rejection of divorce and abortion has resulted in a loss of adherence to it by some Chileans (Meacham 1994:94-96). According to Schmidt (2010:2 of 4 ), even though $70 \%$ of Chileans regard themselves as Catholic, very few attend mass and $73 \%$ of young Chileans do not 'identify with any religion in particular.' Increased secularisation presents not only the Catholic Church, but the many small Protestant (e.g. Evangelical and Charismatic) churches with a significant challenge. It is incumbent on the church as a whole to propagate a vision that includes the need to strive for community, social justice and a dedication to the common good.

In South Africa, between 1948 and 1994, the witness of the church against apartheid was mixed, with some supporting the government, others acquiescing and yet others resisting its policies (Bentley \& Forster 2012; De Gruchy \& De Gruchy 2005). In the future, the impact of the church on the government's policies and practices with respect to poverty alleviation will depend on its credibility within civil society. Such credibility will derive from the church's own intellectual and practical involvement in social protection and poverty reduction, and its freedom from the materialism of our time. Despite the growth of secularism, millions of South Africans still attend church weekly. Sunday services, and other activities during the week, are opportunities that must not be missed to make an impact on the thinking, attitudes, character and behaviour of Christians within the home, community and workplace. It can further educate and motivate those of its members who are government employees to implement existing government policies that can significantly reduce poverty.

Many churches have projects that provide skills and education, seek to reduce HIV infections and care for people living with AIDS. Local church initiatives can assist members of their own congregations and families connected with the church who have lost jobs or do not have housing. Even though the church does not have the resources or power of the State, it can make small-scale, practical contributions to reducing poverty as a witness to its calling to serve others. For instance, Verster (2012:70-88) discusses the role of the church as a community of love in informal settlements.

\section{Conscientisation}

A few elements of the biblical witness and the 2000-yearlong Christian tradition of engagement with economic 
matters were noted at the outset of this article. Knowledge such as this is important to banish ignorance, motivate action and enable Christians to resist the false blandishments of the prosperity gospel now so prominent on the African continent, and to work towards the significant reduction of poverty. These elements of the church's tradition need to be common knowledge beyond the circle of academic theologians in order to instruct and inspire Christians at all levels to provide ethical critique of modern-day social policies that are inadequate or lack implementation. Additional intellectual analysis of the relevant texts, social and economic ethics and a keen understanding of the complexities of poverty reduction also need to be undertaken. In this way, new chapters in the intellectual and practical involvement of the church in the alleviation of poverty can be written in South Africa.

\section{Character, moral will and moral agency}

Many studies emerging from the social sciences are valuable and insightful, but can they address sufficiently the issues of moral character, will and agency? For instance, how is the power of the ancient temptation of greed to be resisted in our time? Christians can contribute significantly, through example and by persuasive argument as to the ethical imperatives of justice and compassion in society (Rakoczy 2006). Christians can further stress that the moral problems our society experiences are rooted in spiritual failure. What moral failure causes a person to ignore the needs of the poor and even to actively rob the poor by engaging in corrupt acts and failing to attend to their urgent needs? Are alienation from God, hardness of heart, an insecure and uncaring avarice and a desire to accumulate wealth and power at the expense of others not at the root of our moral failures? In order for policies of poverty reduction such as the most recent NDP to be effective, thousands of people need to develop and exercise the moral will to implement them, or to engage in strenuous and ongoing efforts to ensure that those tasked with this responsibility actually do so or are held accountable.

For this reason, good policies, technical solutions and the allocation of money - especially if it is being misspent cannot on their own solve problems such as poverty and the lack of health or education. The commitment and efforts of the members of the church, and many others, is required to reduce poverty and suffering and to bring about real changes in people's lives. Without sacrificial care, dedicated work, moral integrity and courage this dream cannot be achieved (Kretzschmar 2012:125-146). Empowered and conscientised churches can both support families and form community organisations that can effect change (August \& Bowers 2004:416-427). In Chile, the effects of the determined implementation of sound policies are clear for all to see. In South Africa much still remains to be done and dedicated Christians can play a significant role in contributing to genuine change if individuals develop their own moral agency and faith communities are active in civil society.

\section{Mutual accountability and the common good}

Christians, who act with the knowledge that they are accountable to God for their actions, or lack thereof, are needed more than ever. If Christian disciples are driven by a desire and determination to pursue what is good for all, the church can be a force for good in our society. Like Jesus, as noted at the outset of this article, Christians need to continue to critique the false values of acquisitiveness and consumption (Nürnberger 2011:59). Church leaders can and must challenge and critique government policies where necessary, and lay Christians skilled in economic matters can propose workable solutions. In particular, the huge failure of delivery or implementation on the part of government needs to be exposed and corrected. Churches have also initiated movements that are mobilising ordinary church members and Christian leaders to take a prophetic stand in all sectors of South African life. When acting within their spheres of influence and in concert, individual Christians, churches and Christian organisations can put pressure on government actually to implement anti-corruption initiatives and policies of poverty alleviation.

\section{The Church and business}

It is significant that the widely-used text, Business ethics (Rossouw \& Van Vuuren 2010), focuses mainly on the importance of businesses being ethical and how this can be achieved at all levels of business operations. However, little space is accorded to socially responsible business and how businesses can fight poverty and unlock human potential (Rossouw \& Van Vuuren 2010:32-38, 126-128). A detailed discussion of the church, poverty alleviation and business cannot be addressed here. Below I simply refer to a few examples of what can and has been done in recent years.

It has already been said that churches need provide some social welfare, promote structural political and economic changes, and hold government accountable. Vorster (2007:113-131) addresses the need for responsible business that can improve the position 'of the poor and needy.' More recently, Fourie (2012:47-50, 57-58) has noted the importance of the engagement of Christians in business, stressing both prophetic and constructive responses. Despite the opposite dangers of being ignored or being co-opted by the business sector, he argues that the power of business to impact on every sector of life across the globe necessitates the active engagement of Christians. Kritzinger (2012:17-34) argues that poverty must not simply be reduced, it ought to be eradicated. He advocates that churches employ the capital of the poor (including the use of 'stokvels', labour, private and communal property as collateral to access loans and effective partnerships). The formation of 'green' businesses that, for example, create small or large vegetable gardens in urban spaces or utilise solar and wind power combine both poverty reduction and environmental concerns.

Christians can give more attention to the formation of business ventures and new entrepreneurial initiatives that can create 
employment opportunities. For instance, Eric Wood from the University of Cape Town has worked with Peter Heslam of the 'Transforming business' (2014) organisation. This organisation investigates the contribution of Christianity to business, combating poverty and extending the wellbeing of human beings and the planet. In cooperation with other groups, it has launched a new venture, the Entrepreneurial leadership initiative that will seek to:

... build relationships of trust and practical synergies to produce specific deliverables that are academically grounded but aimed to stimulate entrepreneurial leadership as a moral and practical solution to socio-economic need. (Elioxford.org 2014:1)

\section{Conclusion}

The Chilean example revealed that poverty can be significantly reduced and the lives of millions of ordinary people transformed. The combination of economic growth and social policies that focused on the family, education, health, the development of skills, the creation of jobs and tax reforms had a significant and positive impact and South Africans can be inspired by their example.

In Chile, the Catholic Church won credibility by resisting the Pinochet regime, helping those who suffered under it, defending the poor and supporting the cause of democracy. Similarly in South Africa, many churches resisted apartheid and supported those who suffered. Today, a new struggle that needs to be undertaken by the church is the fight against poverty, unemployment and the growing gap between the rich and the poor. This requires the development of a moral vision for society. The church as a whole can be conscientised by becoming aware of the biblical witness and the example of other Christians. By gaining knowledge of what poverty is and how it can be combated, it can have a positive impact on the lives of the poor and marginalised by means of individual efforts, medium-sized projects and participation in large scale ventures such as the NDP. ${ }^{13}$ Christians further need to be fully conscious of the danger of being motivated by financial gain at the expense of others and develop the moral character to resist temptation and the moral will to implement effective poverty reduction policies. As was the case in Chile, government efforts to reduce poverty in South Africa cannot succeed without the cooperation and moral accountability of its own officials and society as a whole - and Christians in these sectors have an important part to play. Finally, the church can motivate its members to establish ethical and effective businesses of different sizes to provide employment and lift the poor out of poverty. Thus, the church and other members of civil society need to speak and act decisively so that good policies are devised and actually implemented. In this way, government will be compelled to act as the servant of the people, and not as a rapacious master.

13.Given the debate about the NDP, the Church can also participate in revising it however, an endless debate will not serve the needs of the poor who need antipoverty strategies to be implemented.

\section{Acknowledgements Competing interests}

The author declares that she has no financial or personal relationship(s) that may have inappropriately influenced her in writing this article.

\section{References}

Aliber, M., 2003, 'Chronic poverty in South Africa: Incidence, causes and policies', South Africa: Human Sciences Research Council, Pretoria, World Development 31(3), 473-490, viewed 09 February 2012, from http://www.sciencedirect.com/ science/article/pii/S035750X0200219X.

Armstrong, P., Lekezwa, B. \& Siebrits, K., 2008, 'Poverty in South Africa: A profile based on recent household surveys', Stellenbosch Economic Working Papers, Department of Economics and the Bureau for Economic research, University of Stellenbosch, April, pp. 1-26.

Auditor-General South Africa, 2013, Provincial audit, viewed 10 June 2014 from, http:// www.agsa.co.za/Documents/Auditreports/PFMA20112012/PFMAreportsand pressrelease/tabid/220/ArticleID/82/Auditor-General-buoyed-by-government'srecent-pronouncements-that-firm-measures-will-be-put-in-place-to-strengthenpublic-sector-governance.aspx

August, K.T. \& Bowers, N., 2004, 'Engaging poverty: The Church as an organisation for change', Nederduitse Gereformeerde Teologiese Tydskrif 45(2), 416-427.

Avert, 2012, HIV \& AIDS in South Africa, viewed 15 June 2012, from http://www.avert. org/hiv-aids-south-africa.htm

Baptist World Alliance, 2014, Your network to the world, viewed 29 May 2014, from http://www.bwanet.org/

Bentley, W. \& Forster, D.A., 2012, Between capital and Cathedral: Essays on ChurchState relationships, Research Institute for Theology and Religion, University of South Africa, Pretoria.

Briggs, H.H.Y., 1994, The English Baptists of the nineteenth century, The Baptist Historical Society, Didcot.

Childhood poverty in South Africa, 2002, Alliance for Children's Entitlement to Socia Security, November, viewed 09 February 2012, from http://www.ci.org.za/depts/ ci/pubs/pdf/rights/facts/ch_poverty_in_sa.pdf

Davis, K., 2007, 'On the role of the Catholic Church in politics in Chile', in Berkley Center for religion, peace and world affairs, viewed 08 August 2013, from http:// berkleycenter.georgetown.edu/letters/katharine-davis-on-the-role-of-thecatholic-church-in-politics-in-chile

De Gruchy, J.W. \& De Gruchy, S., 2005, The Church struggle in South Africa, 25th Anniversary edn., Fortress Press, Minneapolis.

Department of the Presidency: National Planning Commission, 2013, National Development Plan 2030: Our future - make it work, pp. 1-444, viewed 11 August 2013, from http://www.npconline.co.za/MediaLib/Downloads/Downloads/ 2013, from http://www.npconline.co.za/MediaLib/Downloads/Down
NDP\%202030\%20-\%20Our\%20future\%20-\%20make\%20it\%20work.pdf

Diakonia, 2006, The Oikos Journey: A theological reflection on the economic crisis in South Africa, The Diakonia Council of Churches, Durban.

Ellsberg, R., 1997, All saints: Daily reflections on saints, prophets and witnesses for our time, Crossroad, New York.

Elioxford, 2014, Entrepreneurial leadership initiative, viewed 10 June 2014, from http://elioxford.org/

Foxley, A., 2004, 'Reducing poverty, sustaining growth: what works, what doesn't, and why', in, Scaling up poverty eduction: A global learning process and conference, Shanghai, China, May 25-27, 2004, The International Bank for Reconstruction and Development/The World Bank, pp. 1-20, viewed 24 February 2012, from http:// info.worldbank.org/etools/docs/reducingpoverty/case/24/summary/Chile\%20 Summary.pdf.

Fourie, W., 2012, 'Can Christian ethics be used to engage business? A (South) African consideration', Acta Theologica 32(1), 46-60. http://dx.doi.org/10.4314/actat. v32i1.3

Frenz, H., 2008, 'A Bishop saving "singers": Tales of torture in Pinochet's Chile', $A$ Journal of Theology 47(3), 251-260.

Gorringe, T., 2001, 'Liberation ethics', in R. Gill (ed.), The Cambridge companion to Christian ethics, pp. 125-137, Cambridge University Press, Cambridge.

Gutiérrez, G., 1974, A theology of liberation: History, politics and salvation, SCM Press, London.

Gutiérrez, G., 1984, We drink from our own wells: The spiritual journey of a people, SCM Press, London.

Habib, A., 2013a, 'Crying out for structural reform', Sunday Times, 21 July, p. 17.

Habib, A., 2013b, South Africa's suspended revolution: Hopes and prospect, Wits University Press, Johannesburg.

Hall, R. (ed.), 2009, Another countryside: Policy options for land and agrarian reform in South Africa, Institute for Poverty, Land and Agrarian studies (PLAAS), University of the Western Cape, Cape Town.

Jansen, J., 2012, 'Opinion analysis', offered by the Vice-Chancellor and Rector: University of the Free State, Bloemfontein, 09 January, pp. 1-2, viewed 28 February 2012, from www.pmi-sa.co.za/documents/Grade_12_Results_2012.pdff' 
John XXIII, Pope, 1961, Encyclical Letter: Mater et magistra, rev. edn., Catholic Truth Society, London.

John Paul II, Pope, 1990, Encyclical Letter: Solicitudo rei socialis, St Paul, Bombay.

Kretzschmar, L. \& Snyman, D., 2008, 'Becoming and being fully human in an HIV positive world: HIV/AIDS and Feminist Christian Spirituality', Acta Theologica, suppl. 11 198-220.

Kretzschmar, L., 2012, 'Towards a Christian ethic of work in South Africa', Acta Theologia 32(2), 125-146.

Kritzinger, J.J., 2012, 'Poverty relief or poverty eradication?', Acta Theologica, suppl. 16 17-34, http://dx.doi.org/10.4314/actat.v32i1S.2 ISSN 1015-8758

Manuel, T.A., 2012, 'NDP Launch Speech by Minister in The Presidency: National Planning Commission on 15 August 2012', in National Planning, viewed 08 August 2013, from http://www.npconline.co.za/pebble.asp?relid $=759$

May, J., 1998, 'Poverty and inequality in South Africa', Centre for Social and Development Studies, University of Natal, pp. 53-58, viewed 09 February 2012, from http:// scholar.google.co.za/citations?view op=view citation\&hl=en\&user=aSscholar.google.co.za/citations?view_op=view_citation
ifvEAAAJ\&citation for view=aS-ifvEAAAAJ:U5HHmVD uO8C

McGuigan, S., 2009, 'Economic ethics: A consideration of the problem of debt', in L. Kretzschmar, W. Bentley, \& A. van Niekerk, (eds.), What is a good life? An introduction to Christian ethics in 21st century Africa, pp. 261-283, AcadSA Publishing, Kempton Park.

Meacham, C.E., 1994, 'The role of the Chilean Catholic Church in the New Chilean democracy', Journal of Church and State 0021969X 36(2), 277-299, viewed 10 March 2014, from http://web.b.ebscohost.com/ehost/detail?vid=12\&sid=283e6d06c90e-4359-88ab-c02a90e4673c\%40sessionmgr198\&hid=114\&bdata=JnNpdGU9Z Whvc3QtbGI2ZSZzY29wZT1zaXRI\#db=rfh\&AN=ATLA0000881259

Mills, G., 2010, Why Africa is poor, and what Africans can do about it, Penguin, Johannesburg.

Moletsane, R., Reddy, V., Ntombela, S., Dayal, H., Wiebesiek, L., Munthree, C., Kongolo, M. \& Masilela, T., 2010, 'Gender and poverty reduction: Voice, dialogue and targeting, Policy analysis and capacity enhancement (PACE)', in Human Sciences Research Council, pp. 1-171, viewed 20 May 2012, from http://www. hsrc.ac.za/uploads/pageContent/624/Poverty.pdf

Nürnberger, K., 2011, Regaining sanity for the earth, Cluster, Pietermaritzburg.

Olavarria-Gambi, M., 2003, 'Poverty reduction in Chile: has economic growth been enough?', Journal of Human Development 4(1), 103-123, viewed 09 February 2012, from http://info.worldbank.org/etools/docs/reducingpoverty/doc/87/file/ Olavarria-paper.pdf

Palma, J. \& Urzúa, R., 2005, 'Anti-poverty policies and citizenry: The "Chile Solidario" experience', in Unesco, pp. 7-36, viewed 24 February 2012, from http://unesdoc. unesco.org/images/0014/001402/140240e.pdf

Pius XI, Pope, 1981, 'Encyclical Letter: Quadragesimo anno', in C. Carlen (comp.), The papal encyclicals 1903-1939, n.p., McGrath, Raleigh, NC.

'Provincial audit outcomes', 2012, South Africa News 24, viewed 30 March 2012, from http://www.southafricanews24.co.za/provincial-audit-outcomes-stagnate/

Quinn, F., 2002, African saints: Saints, martyrs, and holy people from the continent of Africa, Crossroad, New York.

Quintal, G., 2013, 'Time to implement NDP: ANC', IOL News, 22 July, viewed 11 August 2013, from http://www.iol.co.za/news/politics/time-to-implement-ndpanc-1.1550815
Rakoczy, S., 2006, Great mystics and social justice: Walking on the two feet of love, Paulist Press, New York.

Ramphele, M., 2012, Conversations with my sons and daughters, Penguin, Johannesburg.

Rossouw, D. \& Van Vuuren, L., 2010, Business Ethics, 4th edn., Oxford University Press, Cape Town.

Schmidt, M., 2010, 'Poverty, politics and the Chilean Catholic Church', in Berkley Center for religion, peace and world affairs, viewed 24 February 2012, from http://berkleycenter.georgetown.edu/letters/mark-schmidt-on-poverty-politicsand-the-chilean-catholic-church

Sider, R.J., 1977, Rich Christians in an age of hunger: A biblical study, Hodder and Stoughton, London.

Silva, V., 2004, 'The Programa Puente: Bridging the gap between the poorest families and their rights', in World Bank, pp. 1-5, viewed 30 March 2012, from http://info. worldbank.org/etools/docs/library/114527/RTPmaterials/Reaching\%20the\%20 Poor/Session\%207A-Abstracts/Silva.doc

State of Local Government in South Africa, 2009, Overview Report National State of Local Government Assessments, Working Documents, Cooperative Governance Traditional Affairs (COGTA)

Statistics South Africa, 2011, Quarterly Labour Force Survey, Quarter 4, viewed 09 February 2013, from http://www.statssa.gov.za/publications/P0211/ P02114thQuarter2011.pdf

Stassen, G.H. \& Gushee, D.P., 2003, Kingdom ethics: Following Jesus in contemporary context, IVP Academic, Downers Grove, IL.

Tastard, T., 1989, The spark in the soul: Spirituality and social justice, Darton, Longman \& Todd, London.

Terreblanche, S., 2004, 'Armoede in Suid-Afrika', Tydskrif vir Geesteswetenskappe 44, $(2 / 3), 213-240$

Transforming business 2014, Peter Heslam, 2014, viewed 10 June 2014, from http:// www.transformingbusiness.net/dr-peter-heslam2.shtml

Vatican, n.d, Quadragesimo anno, viewed 29 May 2014, from http://www.vatican va/holy_father/pius_xi/encyclicals/documents/hf_p-xi_enc_19310515 quadragesimo-anno_en.html

Verster, P., 2012, 'A Church with the Poor - Lessons from Scripture and from Congregations in Informal Settlements', Acta Theologica, suppl. 16, 70-88. http:// dx.doi.org/10.4314/actat.v32i1S.5 ISSN 1015-8758

Volf, M., 2011, A public faith: How followers of Christ should serve the common good, Brazos Press, Grand Rapids, MI.

Vorster, J.M., 2007, Christian attitude in the South African liberal democracy, Potchefstroom Theological Publications, Potchefstroom.

Wogaman, J.P., 1993, Christian ethics: A historical introduction, Westminster/John Knox Press, Louisville.

Wogaman, J.P. \& Strong, D.M., 1996, Readings in Christian ethics: A historical source book, SPCK, London.

World Hunger Education service, 2013, World hunger and poverty facts and statistics, viewed 24 February 2013, from http://www.worldhunger.org/articles/Learn/ world\%20hunger\%20facts\%202002.htm

Wrong, M., 2009, It's our turn to eat: The story of a Kenyan Whistleblower, The Fourth Estate, London.

Zille, H., 2012, 'Welcome to SA today', Newsletter published by the DA, 13 February. 